Available online at GSC Online Press Directory

GSC Biological and Pharmaceutical Sciences

e-ISSN: 2581-3250, CODEN (USA): GBPSC2

Journal homepage: https://www.gsconlinepress.com/journals/gscbps

(Research ARticle)

\title{
Customary legislations and legal issues of Hilsa fisheries (Tenualosa ilisha) in Bangladesh
}

\author{
Chowdhury Keya ${ }^{1}$, Das Nani Gopal $2,{ }^{*}$, Rani Seema ${ }^{3}$ and Chowdhury Sushmita ${ }^{4}$ \\ ${ }^{1}$ Department of International Law, School of Law, Xiamen University. \\ 2 Institute of Marine Sciences and Fisheries, University of Chittagong, Chittagong, Bangladesh. \\ ${ }^{3}$ International Center for Ocean Governance, Faculty of Earth and Environmental Sciences, University of Dhaka, Dhaka, \\ Bangladesh. \\ ${ }^{4}$ Department of Law, Jagannath University, Dhaka, Bangladesh.
}

Publication history: Received on 19 June 2020; revised on 27 June 2020; accepted on 29 June 2020

Article DOI: https://doi.org/10.30574/gscbps.2020.11.3.0194

\begin{abstract}
Hilsa (Tenualosa ilisha) as a national fish contributes enormous economic and nutritional connotation for the upward development of the country. Its supplies $11 \%$ of the total fish production of the country. About 2.5 million people have been engaged in fisheries industries. Currently, fish production is declining drastically due to over fishing, unruly misleading ways of management and marketing system. This article scrutinizes the present legal issues of Bangladesh fisheries laws and regulations along with its implications. It is recognized that though some fisheries regulating amendments are existed but the proper implementation is yet lack due to several inadequacy of legislations. The limitations of proper legal accomplishment are due to absence of adequate policy framework and guidelines, nonexecution of enactment and conflicts of jurisdictions, reformation of customary laws, revised methods and formation of by-laws, regulations etc. This study reveals some challenges of Hilsa management in Bangladesh and proposes some recommendations to surmount them. Finally, this study enhances the overall improvement of fisheries sectors of Bangladesh utilizing a wide range of legal policy framework and regulations.
\end{abstract}

Keywords: Hilsa fishery; Fisheries Laws and Regulations; Challenges and Legal Issues; Impacts of Bangladesh.

\section{Introduction}

Bangladesh has acquired massive wetland area along with several species based ecosystem. Among $147570 \mathrm{sqkm}$ areas, about 230 rivers and streams cover a total length of $24000 \mathrm{~km}$ surge downward throughout the country [1]. Fishery sectors play a noteworthy role in employment, globalization of the fishing business, supplying nutrition and generate revenues to increase the economic growth of Bangladesh. There are 795 species of fish available in the marine and fresh waters arena of Bangladesh [2]. Only Hilsa fish production was 3.95 lakh MT and the growth rate was $2.01 \%$ where as the total fish production was 38.78 lakh MT and the growth rate was 5.27\% in the FY 2015-2016 [3]. Fisheries contribution was 3.69\% to the National GDP, $23.12 \%$ to the Agricultural GDP and total export earning was $2.01 \%$ in the FY 2915-2016 [4]. Bangladesh earned around BDT 430994.00 lakh by exporting 68.94 thousand metric tons of fishery products in 2017-18 [5]. Among fishery industries Hilsa (ilish) fish business is one of the most prominent sectors in Bangladesh. Three different types of Hilsa shads are existing: Tenualosa toli, Hilsa kelee and Tenualosa ilisha in Bangladesh. Hilsa (Tenualosa ilisha) belongs to the Family Clupeidae [6]. It is commonly found in Southeast and South Asia's fresh and marine water [7]. Among total fish production Hilsa alone contributes $12 \%$ and shares at least $1 \%$ to the total GDP of Bangladesh. Globally about 70\% of Hilsa has been supplied to the market by the country. Only in Hilsa fisheries sectors five lakh fishermen are employed and 3.949 lakh MT's Hilsa was caught in the fiscal year 2015-16 [3].

\footnotetext{
${ }^{*}$ Corresponding author: Das Nani Gopal
} 
After the execution of an inclusive Hilsa protected and natural renewable sources program initiated by the Bangladesh Government the growth rate of Hilsa production increased up to 5.17 lakh MT in the year 2017-18. Since then Bangladesh Department of Fisheries announced Hilsa to be accounted as the Geographical Indicator (GI) registered under the Department of Patents, Designs and Trademarks (DPDT) for its diverse economic growth factor. GI certification enhances the Hilsa more demandable and expensive in both the local and export market due to the increased price range at least up to $10 \%$ to $30 \%$ which helped the manufacturer's earn more revenues [8].

The British colonial ruler of Indian subcontinent was first acted out the fisheries laws and regulations in 1757 [9]. After this several laws and policies were introduced and granted, changed and revolutionized by the court and parliament. As per many experts though numerous legislations are vindicated but those legislations are inappropriate and inadequate for specific areas of management. Some of the legislations are the government's misalignments, full of impuissance, fluctuated and conflicted decisions. Findings of the study shows that Hilsa shad management is under severe threat due to not only the rising fishing demands and environmental factors but also the misleading of laws and inappropriate legal implications in all aspects of fisheries industries. For example, Government has imposed executed pressure on available fish stock to increase exporting fish from an overexploited fishery rather than to sort centralized management to increase inward customer demand in the local market. Therefore, it is essential to inspect legal condition and managerial practices of Bangladesh fisheries sectors and find out proper legations to mitigate the problems for the sack of economical development [9]. The objectives of the study is to examine the previous and current laws of Hilsa fishery, existing legal issues and challenges of Bangladesh in hilsh fisheries sectors, accessible Hilsa management strategy to identify overall ideas of Hilsa fishery legislations for reformation.

\section{Materials and methods}

The exploration of entire study is based on secondary data sources collected mainly from the peer-reviewed journals, newspapers, periodicals, workshop and conference reports, books, legal ordinance of Bangladesh, fisheries related articles, marine policy reports etc. Entire collected data were evaluated, synthesized and the pertinent theory was utilized.

\section{Results and discussion}

\subsection{Institutional framework and governance of Hilsa shad in Bangladesh}

\subsubsection{National fisheries policy and strategy of Bangladesh}

Bangladesh Ministry of Fisheries and Livestocks (MoFL) is the monitoring and controlling authority of the Department of Fisheries (DoF) established in 1975, Bangladesh Fisheries Development Corporation (BFDC) established in 1964 and Fisheries and Livestock Information Department (FLID) established in 1986. Bangladesh Fisheries Institute (BFRI) was established in 1984 which is a sovereign institute activating under the Ministry of Fisheries and Livestocks. BFRI has been researching on inland fisheries and lake management, marine fisheries, freshwater and brackish water aquaculture, fish diseases, fish genetics etc. [10]. DoF imposes administrative rulings towards conservation of marine fisheries and ecological unit; BFDC imposes rules and guidelines towards fishing sectors training, production and marketing; and FLID has been working for protection of distribution and fisheries livestocks abide by the rules and regulations of The National Fisheries Policy, 1998 (Table 1) and The National Fisheries Strategy, 2006. Marine environment protection jurisdictions are also imposed by the Ministry of Environment, Forest and Climate Change.

The National Fisheries Strategy, 2006 executed the guidelines of the National Policy, Poverty Reduction Strategy Paper (PRSP) and The Road Map of PRSP. This strategy consists of eight sub-strategies including fresh water aquaculture, extension of aquaculture, shrimp culture, marine capture fisheries, inland capture fisheries, development of human resource management, evaluation and monitoring (Fig.1). Except the marine sector sub-strategy, the other seven substrategies do not replicate the precautionary principles. These eight sub-strategies are shaped to prop up and steer the National Policy whereas the marine fisheries sub-strategy directs the marine fisheries management plan rooted in the guidelines of the precautionary principles. This strategy is basically formulated to persuade several agencies and partners sustaining the fisheries resource management to diversify its stable use for gaining the vision of Bangladesh National Fisheries Policy and Guidelines [12]. 
Table 1 Key areas and objectives of Bangladesh National Fisheries Policy (NFP), 1998 embarked the policy framework for intending the management of the fisheries sector

\begin{tabular}{|c|c|}
\hline Key areas & Objectives \\
\hline $\begin{array}{l}\text { Policy for conservation, management and exploitation } \\
\text { of fisheries resources } \\
\text { of the inland open water bodies (Inland Capture } \\
\text { Fisheries) }\end{array}$ & $\begin{array}{l}\text { Enhancement of the fisheries resources and } \\
\text { production; }\end{array}$ \\
\hline $\begin{array}{l}\text { Policy for fish culture and management in inland } \\
\text { closed water bodies (Aquaculture); }\end{array}$ & $\begin{array}{l}\text { Poverty alleviation through creating self-employment } \\
\text { and improvement of socioeconomic conditions of the } \\
\text { fishers; }\end{array}$ \\
\hline Policy for Coastal shrimp and fish culture & Meet the demand for animal protein \\
\hline $\begin{array}{l}\text { Policy for exploitation, conservation and management } \\
\text { of } \quad \text { marine } \\
\text { (Marine) }\end{array}$ & $\begin{array}{l}\text { Achieve economic growth and earn foreign currency } \\
\text { by exporting fish and fisheries } \\
\text { products; }\end{array}$ \\
\hline $\begin{array}{l}\text { Other related fisheries policies (Quality Control; } \\
\text { Planning Monitoring and Evaluation; Extension; and } \\
\text { Human Resource }\end{array}$ & $\begin{array}{l}\text { Maintain ecological balance, conserve biodiversity } \\
\text { and improve public health }\end{array}$ \\
\hline Development) & \\
\hline
\end{tabular}

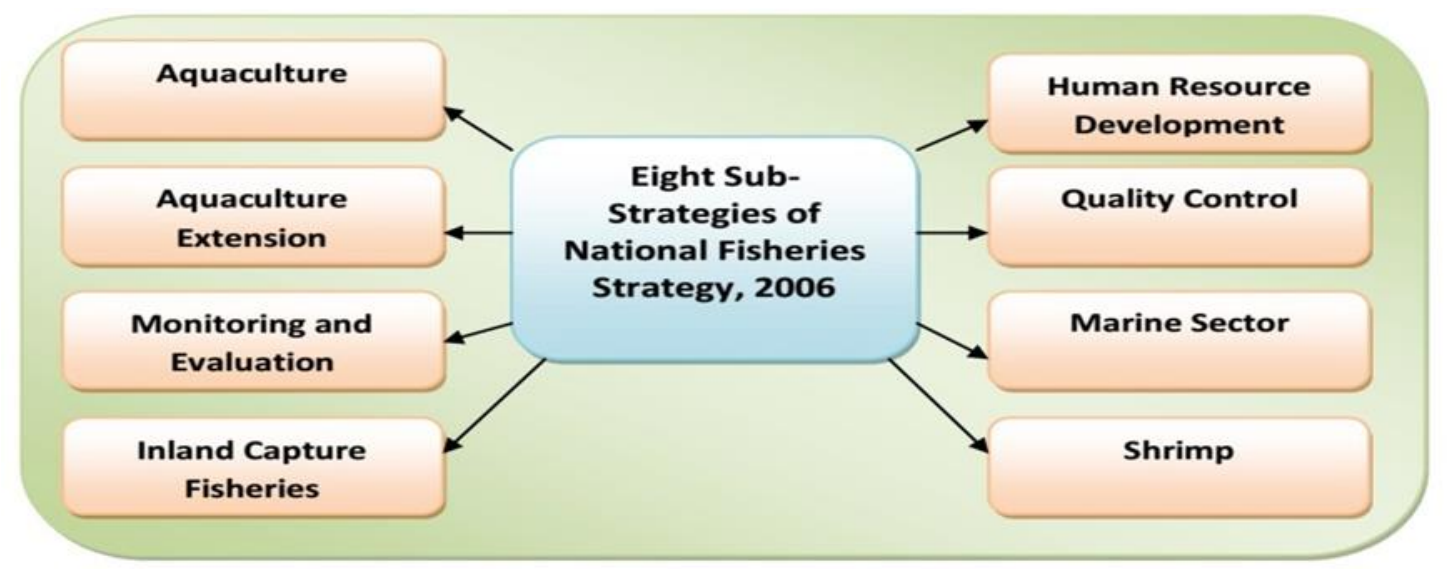

Figure 1 Eight sub-strategies of National Fisheries Strategy (NFS), 2006

Source: DoF, 2006 [12]

\subsubsection{National policy framework for inland brackish/fresh/open water bodies}

New Fisheries Management Policy (NFMP) was inaugurated by MOFL in 1986 aiming to attain numerous goals, for instance - creating benefits from the harvesting of government owned fisheries to the original fishers striving on the water from the intermediaries lease holders who are related in abolition of profits from the fishing activities until now and to improve measures for ensuring fishers sustainable livelihood with the intention that the fishery efficiency of inland open water can continue. According to the Ministry of Land Memorandum 1991 [13], entire open water fisheries management shall consider as income source of sub-district (Thana) and the factions of income returns would be allocated of diverse sub-districts based on the population of the area (Ministry of Land Memorandum 1991). In the last 15 years the share of inland capture fisheries has declined from $40 \%$ to $27 \%$ [10]. The declining rate or steady growth rate of open water fisheries has become a great concern which needs to set proper policy formulation and management by the Government. Hence, BFRI expanded Fisheries Research Vision 2015 up to 2020 with a target of fish production of 5.4 MT in 2020 [14]. The Vision strategy as proposed was "Conservation of water bodies first and fish production next" and "Every water body is a fishery water body" [10]. 


\subsubsection{Precautionary principles}

Protection and Conservation of Fish Act, 1950 was amended on 1995 to minimize the declination of Hilsa and to increase the production which was later on amended by the Protection and Conservation (Amendment) Ordinance 1982, the Protection and Conservation of Fish Rules 1985 and the Marine Fisheries Ordinance 1983. The Protection and Conservation of Fish (Amendment) Act, 2002 was established to impose SRO (Statutory Regulatory Order) to ban producing, marketing and using current net. The Fish and Fish Products Rules 1997 contain 21 sections as of S.R.O. No. 276 Law/97 of the MoFL, 1997 under Ord. No. XX, 1983 established for ensuring licensing system for fish and fish production [15].

Bay of Bengal water bodies of territorial zones, conservation zones, continental shelf and economic zones are regulated by the law and order designated by The Territorial Waters and Marine Zones Act, 1974 under (Part II) of The Marine Fisheries Ord. No. XXXV [16]. This law differentiates the Hilsa fisheries from other fisheries in the Bay of Bengal and the entire alive and lifeless sources existed in the economic arena shall vest absolutely under Republic jurisdictions. As per this ordinance fishing vessel hauling capacity should be under 1 year valid license and the director is empowered to cancel, suspend and refuse license in terms of any illegal or violation of legislations. The territorial fishing boundary limitation of Exclusive Economic Zone (EEZ) of fishing boundary is 200 nautical miles, territorial sea length is 12 nautical miles $(22.2 \mathrm{~km})$ and contiguous zone is 24 nautical miles from the baseline [17] Marine fisheries management, expansion and preservation are regulated by The Marine Fisheries ordinance, 1983 which regulates the managerial implication of enhancing fisheries water bodies that should be more than 40 meters for mechanized fishing boats and industrial vessels. It also imposes restrictions on water bodies of less than 40 meters that have to preserve for artisanal (small-scale) fisheries only. This Act mainly helps to mitigate the conflict between industrial vessels and artisanal fisher's by ensuring one year license agreement of fishing trawlers and every trip should be permitted by DoF. The base law of the Marine Fisheries Ordinance, 1983 was applied through the equivalent rules and regulations enacted by the Marine Fisheries Rules and Amendment in 1993 imposing legal orders to have license of mechanized and nonmechanized fishing boats. License would be cancel due to the breach of restrictions regarding size, sex, age and quantities of fish, use unauthorized fishing gear and fishing during ban periods (Part III) of The Marine Fisheries Ord. No. XXXV [16]. Use of any forbidden fishing methods such as: use of explosive, poison, noxious substance, any intentional killing, immobilizing or catching fish, having fish without legislative excuse are accountable as breach of laws (Part VI) of The Marine Fisheries Ord. No. XXXV [16].

Under the Protection and Conservation of Fish Rules 1985, to enhance Hilsa production four juveniles' sites were converted into Hilsa sanctuaries in 2005 and the fifth sanctuary was developed in 2011 (Table 2 and Fig. 2). As per this amendment, any type of fishing is banned for certain periods for each year in these five sanctuaries. Another four Hilsa spawning grounds have been identified for gravid fish to spawn properly and declared as ban period for 11 days of October in each year (Table 3). At present, it is banned for two months and five days from 20th March to 23rd May. Any kind of gear will be seized or forfeited by the breach of restrictions of catching fish in these areas during ban periods. Use of current net (gillnet prepared by mono-filament synthetic nylon fibre) was banned in 1998 (under 2002 amendment of the Fish Act, 1950) and using gill net of less than $10 \mathrm{~cm}$ mesh size is illegal. Breach of this law must entail penalty that has been authorized by the metropolitan or first class magistrate as mentioned in Section 6 of Act, 1950 [18]. Catching jatka and broodstock is completely prohibited by using the law of the Act, 1950 [19]. Jatka should not be caught before they attain the size of $25 \mathrm{~cm}$ as decided by SRO No. 92-law/2013 of the MoFL, 2013 [20].

Table 2 Developed Hilsa sanctuaries of Bangladesh.

Source: Bangladesh Gazette, 2014 [21] and Rahman 2017, [22]

\begin{tabular}{lll}
\hline Locality & Hilsa spawning ground & Border length (km) \\
\hline Bhola & Paschim Syed Awlia point, Tajumuddin & 80 \\
Cox's Bazar & North Kutibdia point, Kutubdia & 120 \\
Chittagong (Chattagram) & Mayani point, Mirsarai & 125 \\
Patuakhali & Lata Chapali point, Kalapara & 194 \\
\hline
\end{tabular}




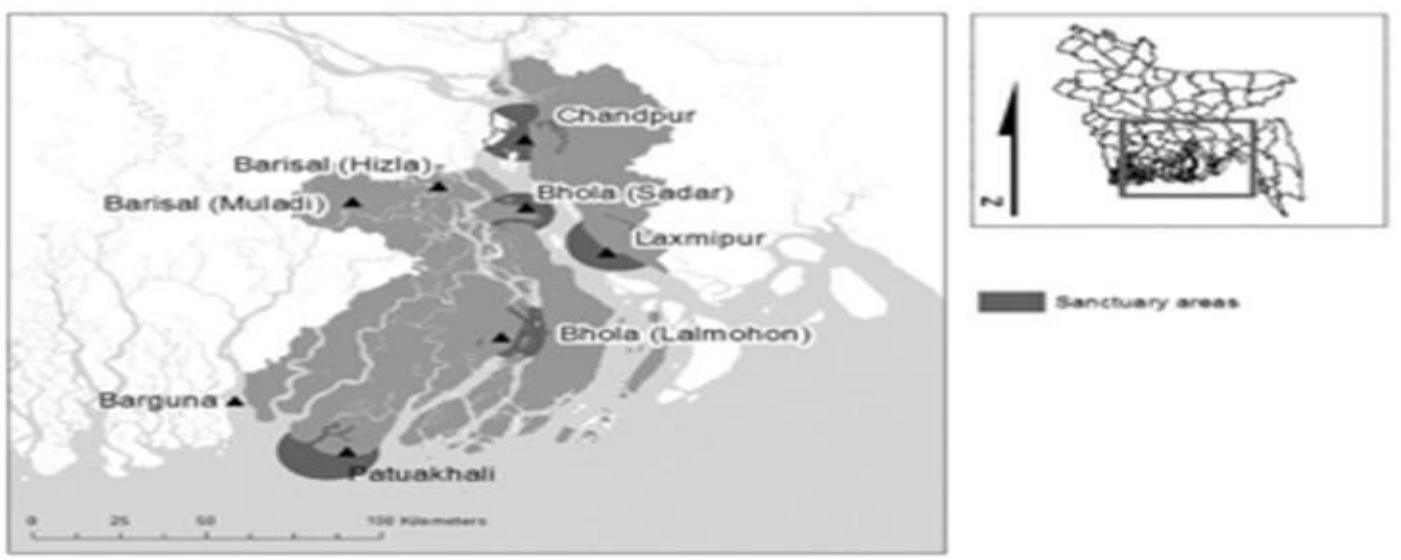

Figure 2 Map of Bangladesh Hilsa sanctuaries

Source: Bladon, 2018 [23]

Table 2 Ban period restrictions on Bangladesh Hilsa fishing

Source: Bangladesh Gazette, 2014 [21] and Rahman, 2017 [22]

\begin{tabular}{|c|c|c|c|c|}
\hline Sanctuaries & $\begin{array}{l}\text { Border } \\
\text { length }(\mathbf{k m})\end{array}$ & Water zone & Restricted period & Locality \\
\hline $\begin{array}{l}\text { Shantnol to } \quad \text { Char } \\
\text { Alexander }\end{array}$ & 100 & Lower Meghna estuary & March to April & $\begin{array}{l}\text { Laxmipur, } \\
\text { Chandpur }\end{array}$ \\
\hline Char Illisha to Char Pial & 90 & $\begin{array}{l}\text { A tributary of Meghna } \\
\text { river, stretch to } \\
\text { shabajpur channel }\end{array}$ & March to April & Bhola \\
\hline Bheduria to Char Rustam & 100 & Stretch to Tetulia river & March to April & Patuakhali, Bhola \\
\hline $\begin{array}{l}\text { Kalpana Golbunia point to } \\
\text { the Confluence of Bay of } \\
\text { Bengal and Andharmanik } \\
\text { river }\end{array}$ & 40 & Andharmanik river & November to January & Patuakhali \\
\hline Tarabunia to Vomkora & 20 & Lower Padma River & March to April & Shariatpur \\
\hline
\end{tabular}

\subsubsection{Managerial and conservation strategies of Hilsa in Bangladesh}

Bangladesh Fisheries Investigation and Management Department was first established at Chandpur in 1981. International Development Research Centre (IDRC) donated two years of financial support of US $\$ 300,000$ dollars in 1984 for hilsa exploration. The Ministry of Fisheries and Livestock (MoFL) executed a new fisheries management policy that dealt with overexploitation and inequality of fishing rights in 1986. To increase Hilsa production and distribution, Bangladesh Department of fisheries executed Hilsa Fisheries Management Plan (HFMAP) in 2003 which enclosed the strategies of the complete ban of catching, transportation and selling juveniles and brood Hilsa; plus compensated by cash for not having work during the breeding seasons [24]. Among the world fisheries management, this is one of the most exceptional instance of "carrot-and-stick" incentive- based managerial strategy imposed by Bangladesh. Government of Bangladesh (GOB) proclaimed four sanctuaries for the upliftment of Hilsa production in 2005 [25]. After the successful outcome of the incentive based intervention the Darwin Initiative of the UK provided some supportive scientific hilsa research and awareness edifice actions in Bangladesh. Under conservation strategy Government has taken initiatives called "food compensation scheme" works through a chain of command to the fishers (Fig. 3) which is funded by the Vulnerable Group Feeding (VGF) to diminish food uncertainty. At first, Government had given $10 \mathrm{~kg}$ of wheat among 145,335 fishers for 1 to 3 months of the year based on some selected areas in 2008. Around 224,102 fishers were enlisted of receiving incentives of $40 \mathrm{~kg}$ rice and some amount of cash per month during the ban fishing season from the year 2014 [26]. 


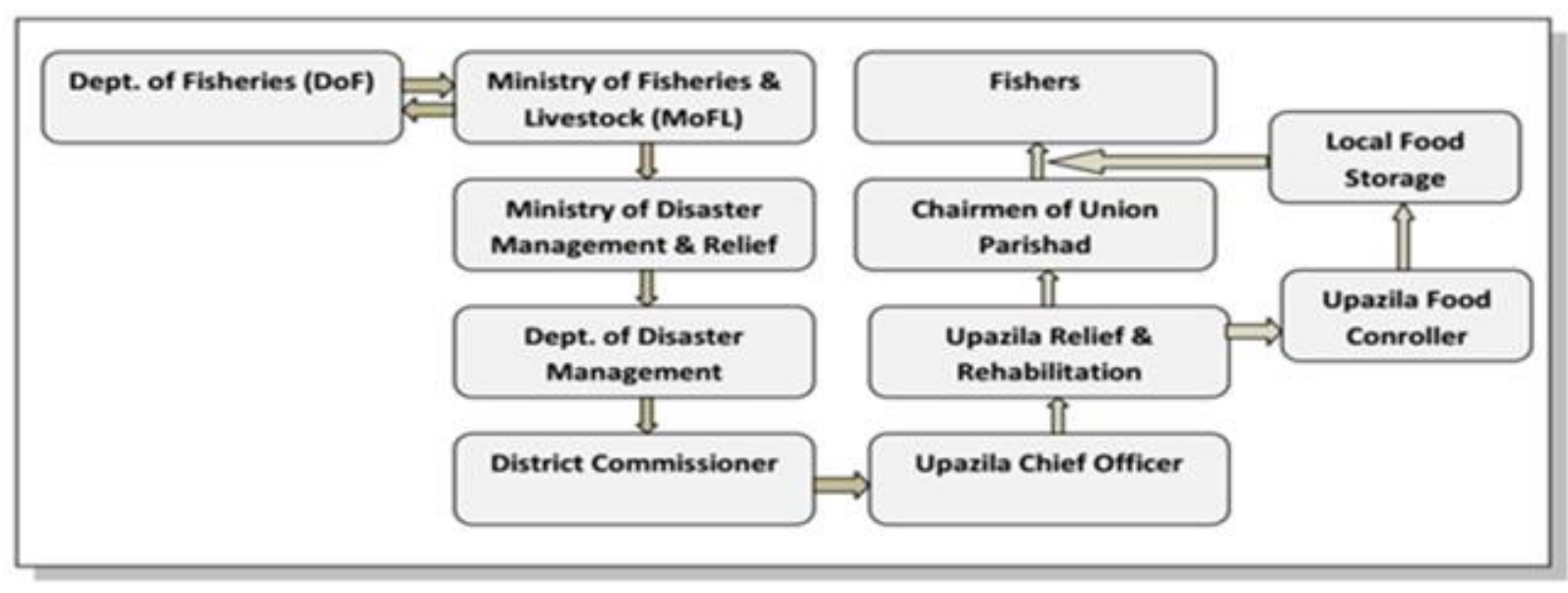

Figure 3 Bangladesh food grain distribution flow chart

Source: Islam, 2016 [20]

The Government distributes the leaflets, banner, poster and announcing verbally around the sanctuary areas to develop awareness to the fishermen and those who are related to the Hilsa fishing industry. Moreover, securities and law enforcing agencies are imposed to stop people of violating the laws [27]. Under Alternative Income-generating Assistance (AIgA) some alternative jobs are offering to small scale, fishermen to develop their livelihoods through few NGO's and micro-credit organizations at the time of ban period.

Bangladesh Government has also initiated incentive-based approach twofold strategy "PES scheme (Payments for Ecosystem Service)" in 2003 which is basically widely used for conserving natural resources like forest, water-lands but in Bangladesh, this scheme instigated for imposing Hilsa fishing ban and providing economic incentives to improve the socio-economic condition of the fisher's livelihood. PES scheme is legally obligatory by environmental standards, compliance assessment instrument, judicial and enforcement practices and a proper institutional framework [28]. IIED (International Institute for Environment and Development) and partners are working with the Bangladesh Government for allocating this PES scheme to persuade fisher's mind and raise awareness about exploitation of Hilsa. The main objectives of the IIED and partners are to build trust among the fishers and stakeholders towards the Government officials. To shield marine ecosystem and prop up fisher's living, IIED and partners are functioning to put a tri-country management system among Bangladesh, Myanmar and India [29].

Bangladesh has also taken adaptive management based fisheries strategy by establishing National Climate Change Fund around \$100 million US dollars under Bangladesh Climate Change Strategy and Action Plan (BCCSAP), aiming for alteration of climate change consequences, adapting techniques and appropriate measures of capture fisheries, maintaining fishing communities steady yield and standard of living in the areas of skill development implementation, aquatic habitat restoration and conservation of biodiversity, fisheries stock enhancement, water body management, uninterrupted and unhampered migration of fishes [30]. The Environmental Policy 1992 also has the significances for Hilsa preservation which defines the expansion of fisheries assessments that has collisions on its resource [31].

\subsubsection{Establishment of MPAs to enhance the institutional capacity of Hilsa management}

Bangladesh Government has taken several initiatives to develop and improve its Marine Protected Areas (MPAs) as a Hilsa protection strategy along with other marine wild species in 2014 under Wildlife Conservation and Security Act No. XXX of 2012 [32]. Swatch of No Ground Marine Protected Area (SoNG-MPA) was signed by law in 2014 by the Ministry of Environment and Forest (MoEF) also that covers the obstacles surrounded by the territorial water borders of India. A social science research agenda for marine protected areas, 2003 declared - developing MPAs is the initiative basically working for dented habitats rehabilitation, biodiversity preservation, development of ecosystem, environmental hazards alleviation, fish brim over into regional fisheries, generate ecological and executive insecurity insurance, moderate scientific research, refurbish continuation of fisheries, increase economic chances, enhance empowerment of coastal neighborhood, generate tourism promotion and artistic advantages [33]. 
The first goal of this strategy is to focus on social and economical status of fish communities by imposing rules of preservation, conflict resolution mechanism, corporate legislation and compliance measures, management, communal integrity and split economical assistances [34].

Bangladesh declared Nijhum Dwip as Marine Protected Area situated in the northern Bay of Bengal with co-operation of funding by the national partner Wildlife Conservation Society (WCS) and Rainforest. It is assumed that this initiative will preserve around 15 endangered marine species along with spawning ground of Hilsa and its roots of migration. This will also ensure the safety of marine biodiversity, mitigate global risk, ensure food security, improve living and enhance economical income [32]. This announcement will earn benefits for Bangladesh to mitigate its national and international requirements of United Nations Sustainable development Goal 14 and Convention on Biodiversity Target 11. Target 11 aims to establish well associated management coordination of protected zones; and also to protect $10 \%$ coastal and marine areas and 17\% of terrestrial and inland water areas by 2020 [35]. Goal 14 is required for to support small scale fisheries, impose jurisdiction upon protected areas expansion to enhance marine biodiversity, maintaining national treaties for ocean resources management, sustainable development of fish, control ocean acidification and eutrophication, assess climate change factors, mitigate overfishing, and organize illegal, unregulated management and unreported distribution [36].

\subsubsection{The implementation of CBFM-2 project - phase 2 (2001-2007)}

A 2 Phase Community Based Fisheries Management project (CBFM-2) was implemented by the DoF under the supervision of GoB along with the support of World fish Center in between 2001 to 2007. Eleven NGOs (Non Governmental Organizations) were involved in the project to develop 130 communal organizations and 116 inland water bodies' management. The project work identified around 4 million hectares of floodplains that could be beneficial through the development of fisheries management [37]. The main goal of this project work was to do policy formation for enhancing pro-poor sustainable fisheries management and functional activities. The legal advice and support were controlled and supervised by the NGO - BELA (Bangladesh Environmental Lawyers Association) [9]. After completion of the project it was identified that the community management has progressed its potentiality and the condition of the fishermen community has improved and the sustainable fisheries management has potential to boost the living of people involved in this fisheries management. At present Community Based Management Approach is one of the optimum parts of policy concentration philosophy (Fig. 4).

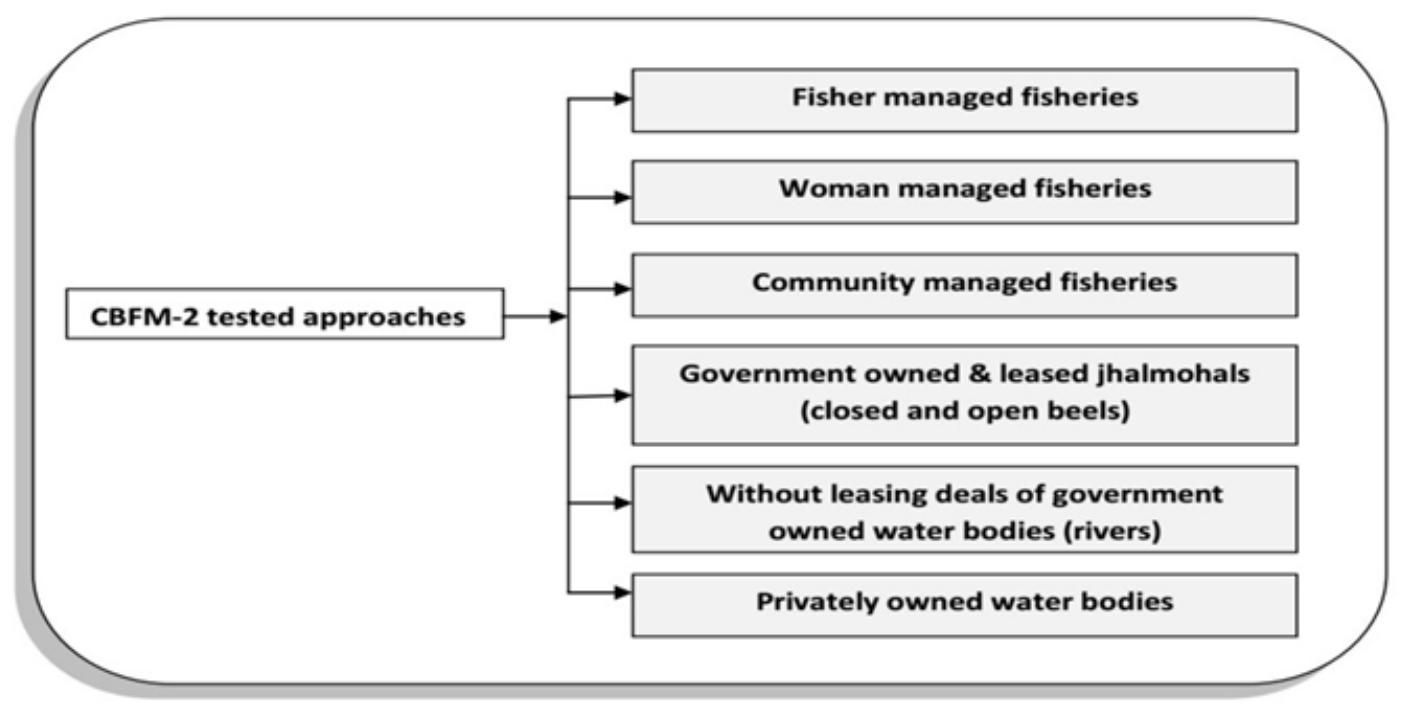

Figure 4 Approaches of CBFM-2 project.

Source: Ministry of Fisheries and Livestock (MoFL), 2006 [38]

\subsubsection{Execution of law enforcement agency "Mobile Court" in Bangladesh}

Mobile court is a moveable institution authorized to adjudicate disputes by magistrates on the spot for the breach of laws executed by the Bangladesh Standard and Testing Institute under Amendment Act, Section 33 [39]. Under the Mobile Court Ordinance 2007, the mobile court can activate at the time of fishing during ban period and enforce 
adjudicate punishment for the violation of the laws. If necessary it can also seek for the protection from the national defense force of police and agencies under 1898 Code of Criminal Procedure, Act V [40].

\subsubsection{USAID'S supportive initiatives towards Bangladesh Hilsa fisheries development}

To enhance the Meghna River Ecosystem and Coastal fisheries communities in Bangladesh, World-Fish USAID initiated five year plan project "Enhanced Coastal Fisheries in Bangladesh (ECOFISH ${ }^{\mathrm{BD}}$ )" from 2014 to 2019; worked jointly with the DoF under the Government of Bangladesh aiming to focus on the development of food security in the course of research based fisheries management programs and boost up fishers livelihoods related with Hilsa fisheries. These are also dealing with unreported, illicit and unfettered fishing, climate change factors and fighting for the widen strengths of fishers especially women capability to dig out utmost advantage from the coastal environments. Furthermore, to develop hilsa shad habitats, it has been inaugurated an adaptive community based integrated coastal management; for instance - national fisheries policy, the coastal zone policy, national water policy, inland capture fisheries sub-strategy and marine and coastal sub-strategy under the national fisheries strategy and action plan, and national adaptation plans of action in Hilsa sanctuaries enhancing focused on factors to decrease catching of artisanal (small-scale) fisheries [41]. The result of this project forecasted that Bangladesh water has potential to harvest huge Hilsa biomass and the exploitation level of Hilsa grows higher which steadily moving towards optimum level up to FY 2019 (Fig.5). One more positive achievement of this project is that it can manipulate the Hilsa management to accept $6.5 \mathrm{~cm}$ mesh size gillnets in Hilsa fishing; and the Government will shortly enroll this recommendation under gazette notification[42].

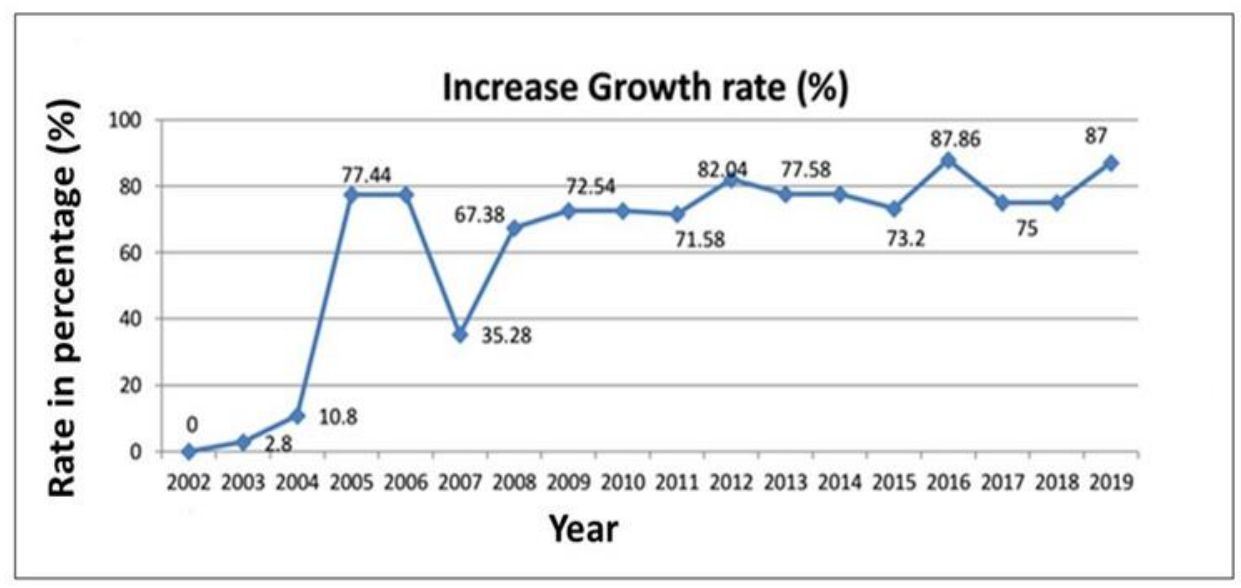

Figure 5 Growth rate (\%) of Hilsa in Bangladesh.

Source: Modified after the World Bank, 2018 [43]

\subsection{Challenges and legal issues of Hilsa management in Bangladesh}

Due to unintended and unlimited catching fish along with improper fishing methods not only the size has shown uncertain effect but also, the fish productions are facing wide rages of a hindrance on its management and marketing channels. The fishing nets cause barriers to migratory routes, the expulsion of industrial waste, siltation of rivers, embankment construction, sluice gates, sewage, agricultural rubbish, dumping poisonous chemical into the riverine water, ship breaking, natural calamities, climate the alteration, smuggling of Hilsa etc. These factors distract the management of Hisha as well as overall fisheries industries of Bangladesh. `As a result, these also become the causes of environmental destructions, losses of biodiversity, scarcity, stake-holder's conflictions, social stress, starvation and uncertainty.

Though catch jatka (fingerling size/juveniles) is completely illegal under 'the 1950 Protection and Conservation Fish Act' but yet they are continuously caught in huge quantities by gillnets in their immature size and sell them at the neighboring market [21]. More than 19,000 jatka (juveniles) were caught from rivers and seashores in the year 2000. Even if jatka is catching all year round but commonly has caught at the time during January and May, maximum in April nearly about 45\% [44]. Majority of jatka are caught illegally in between November and June as it is strictly prohibited to catch in these months [45]. Due to the lacking of alternative work to maintain their living; poor fishers have chosen to do illegal activities of catching jatka during the banned period [46]. This kind of mistreatment of the juvenile fish has created severe penalty on overall Hilsa catching and maintenance [47]. Though there is a strict prohibition of catching 
brood Hilsa at the time of spawning season from their breeding grounds, many fishers have been violating the laws and catch the brood Hilsa for making higher profits as of high demand in both neighboring and international market. Normally in the boundary of Bangladesh and Myanmar Hilsa has been caught less than 25.7cm (weighted 300-500g) whereas the fish can grow up to $50 \mathrm{~cm}$ (weighted $3 \mathrm{~kg}$ ).

Increasing population growth factor is another great problem in Hilsa fisheries industry. Due to too many fishers are being involved day by day in the same occupation, they could catch only a few amounts per person. Since ancient time though fishing has been treated as an occupation of Hindus community living nearby coastal areas but due to the rising of the unemployment problem, presently too many landless poor Muslims have been engaged in this profession. That's why; fishers are attempting to do some illegal means for mitigating their basic needs of livelihood. Besides, as there is free right to use the open water body and higher local market demand of Hilsa with a high price; fishers disobey the laws and regulations of the fishing ban for taking the opportunity of some additional income.

Ultimately a huge amount of fishing boats are being increased in the nearby riverine water areas which lead to water pollution. Study shows that currently in some fishing areas fishers are coming from other regions for fishing and most of them do not belong to the fisher families even. They have taken this occupation as of their part-time job for earning more money and on the other hand they have been breaking the laws of prohibition act of fishing. As per experts, due to overfishing, the fisheries industries of Bangladesh have been suffering from the arbitrary yield of gravid fish and arbitrary catching of jatka.

Nowadays, destructive cause of Hilsa migration as well as breeding is due to temperature rising, water pollution and salinity increase. Due to the increasing of siltation and decreasing of rainfall over the year, the possibility of spawning by brood fish trends to be decreasing. Dumping industrial waste into the river water and construction of barrages to the upstream resulting the siltation and water pollution are continuously violating the laws of Bangladesh. This pollution is also a reason for destroying the natural spawning ground of Hilsa. Government has endorsed many projects of coal-fired power plants nearby the area of Hilsa sanctuaries. As a result, several types of carrying vessels are transporting, discharge oil and waste into the river water which may cause serious harm to the Hilsa fisheries.

Nets and engines are treated as major fishing equipments in Bangladesh. Size of gillnets less than $10 \mathrm{~cm}$ and of current jal $4.5 \mathrm{~cm}$ is not allowed by the laws of "The 2002 amendment to the Protection and Conservation Fish Act, 1950" [18]. Before fishers were used cotton nets by which only big fishes can catch but at present, they are using illegal gillnets, current jal, and faster motorboats in the banned fishing zones that have caused massive violations of laws. Some fishers have used so hi-tech powerful motor engines in the compassion of law enforcement authorities by which they can violate the law easily of doing illegal activities. Some laws and regulations are enacted but the implications are not yet utilized properly. For instance, despite the strict restriction of the court 2002 amendment to the Protection and Conservation of Fish Act, 1950 [19] still manufacturer are producing current jals which are parched and used by the fishers [20]. Government officials are only catching, fined and leave them but they are not taking steps to stop such type of illegal activities permanently.

To protect Hilsa during the breeding period the Government took an incentive program of providing $40 \mathrm{~kg}$ rice and cash support to cover family expenses including children's educational expenses for each month to the fisher's family. Some of the fisher's family members are more than eight people. Therefore, $40 \mathrm{~kg}$ rice is not sufficient for them. Many of the fishers do not get this incentive timely; some fishers only get 30-35kg due to impious activities of some Government official deceivers and political corruption. Also, some fisher names are not enlisted in the beneficiary list, only $52 \%$ of fishers have fishermen identification card [34]. Even some real fishers are excluded from the list whereas some nonfishers are enlisted due to bribery.

The enactment of the fishing ban is not properly maintained in some sanctuaries. Erroneous segregations of sanctuaries denote the improper distribution of incentives to the non-target fisher's. Sometimes ban periods are imposing ban to the entire fishing whereas incentives are only given to the Hilsa fishers which provoke the non-Hilsa fishers to gets involvement in Hilsa fishing activities to gain incentives.

Hilsa is a migratory trans-boundary species. The contribution of Hilsa to the export markets are about $76 \%, 15 \%$ and $4 \%$ from Bangladesh, Myanmar and India respectively. Though Bangladesh has strict laws of enforcement to ban fishing during the breeding season, but Myanmar and Indian fishers have no such laws and regulations to protect Hilsa population. This could also violate the managerial process of Bangladesh to the development of Hilsa sectors. 
In fisheries industry, many categories of people and organizations are involved to a fishing chain such as personnel money lenders, fishers, government officials, fisheries department, NGO's, police, law enforcement department, coastguard, banks, business intermediaries etc. Hilsa sanctuaries often become a victim of their miss guidance and interpersonal conflictions. Many people of this chain try to make their own benefits illegally by violating the laws and regulations. To buy fishing equipment majority of the fishers are often taking loans from the personnel money lenders and the micro-credit organizations such as BRAC (Bangladesh Rural Advancement Committee) and some other NGO's due to non-available bank loans as they have nothing to a mortgage. As a result, these money lenders and micro-credit organizations proposed conditions to the fishermen to sell their fish only to them. Therefore, real fish stakeholders cannot make any profit from their fish rather than stuck into a debt cycle. Even sometimes it will be impossible for these poor fishermen to pay back the full amount of loans and higher installments. Due to non-payment of the debt, they seize fisher's belongings including fishing boats, nets as well as fish. So to pay back the loans and maintaining their livelihood, poor fishermen have always to violate the law by participating in illegal fishing activities.

Due to the negligence of their prime duties of the coastguard and lack of Government concern and protection initiatives, fishermen are often frightened about pirates attack in the peak seasons. It is quite common in Bangladesh that the pirates seize the fishermen boats, fishing nets, money and even sometimes commit murder. Furthermore, DoF officers are also disregarded by the Government of not getting any adequate compensation for their crucial and sometimes riskier duties such as: enacting laws against illegal fishing, staying middle of the river or ocean during nights, active on duties during holidays.

Lack of social bonding, interpersonal conflictions among fishermen, money lenders, boat owners and government officials often occurred to physical injury, damage fishing properties and social pressure in between communities and administrations along with serious violation of social norms and regulations. Moreover, there are some limitations between rights of fishing quantities and communities fishing zone of catching fish. Some fishers are powerful, linked with political bodies; so they themselves take the decision of the fishing area limitation for the poor fishermen. They have mechanized engine boats which also help them to catch maximum amount of fishes so faster than the nonmechanized fishing boat owners. These mechanized fishing boat owners are often giving bribes to the law enforcement bodies to hide their illegal activities at the time of raid and fishing during the nighttime in banned seasons or in the restricted fishing zones.

Alternative Income Generating Assistance (AIGA) incentives are required certain eligibility for giving jobs to the fishers during ban seasons. As a result, most of the fishers are disregarded from this facility due to not have adequate eligibility requirement.

DoF officers are not acknowledged about Mobile Court laws and regulations which hampers of taking timely proper decisions and actions. Lack of Magistrate's physical presence on the spot is another major issue to control illegal activities as DoF officers are not sanctioned to take action under The Mobile Court Ordinance, 2007 [39]. Due to inadequate physical resources, mobile court operations often become steady during the raid on illegal activities.

Lack of sufficient research experiences, active qualified participant and financial derivatives of BFRI also hamper the research and development process in Hilsa preservation.

\section{Recommendations}

A number of obstacles and legal issues appear in the practical field of Hilsa management even after numerous initiatives have taken and regulations are already implemented. Though it is necessary to continue fishing ban and lawful prohibition to improve the growth of Hilsa fisheries management but it is also essential to ensure fishers' livelihood during ban season or at the time of imposing any kind of lawful act. The amount of rice given as AIGA compensation should reallocate and coverage should amplify equitably to meet the actual demand; ensure all the real fishers are receiving incentives rather than non-fishers enlisted in the fisher's beneficiary list; and incentives must be allocated to the fisher's hand before the ban periods. Set eligibility requirements should maintain in suitable ways which ensures income source during ban periods for all Hilsa fishers instead of a few. Implementation of strict rules and guidance is to provide proper awareness about incentives and education to the fishers regarding Hilsa fishery management that could lead Hilsa conservation program successful. Community-based fishery co-operatives and co-management strategy is helpful to increase fisher's education towards fishery and their livelihoods.

Though Hilsa is known as seawater fish, however, it moves to freshwater (rivers) for procreation [48]. To preserve Hilsa fish destruction at the time of spawning and development such as - flood prevention activities, road, drainage and dam 
construction, agriculture and irrigation, proper discretion should be applied. For the purpose of increasing fish production and preserve biodiversity, DoF should take the decision to convert the whole jhalmohal or some selected areas into fish sanctuaries; also be liable to take care of the overall managerial process. Fish sanctuaries designed by jhalmohal are to be transferred to the Directorate of fisheries. Immediate action should be imposed due to violation of capturing juveniles during the ban period and banned size Hilsa [19]. Use of harmful banned pesticide on the agricultural zone, the expulsion of industrial waste into the land based water and current net to catch fish is countable as the serious violation of national regulations which must be punishable. Law enforcing bodies and fisher's committee will be employed in the execution of the Fish Conservation Acts. Open water lands such as rivers, canals must not be dewatered and may renovate if necessary.

Scientific policy-based management was utilized to promote BFRI's research capacity which could ensure science-based policymaking process for creating sustainable Hilsa fish management [45]. For the development of scientific and policy based durable Hilsa fisheries management Government should focus more on the development strategies of those branches of DoF which are involved in Hilsa fisheries research and make more investment for doing surveys and research; hire standard researchers or scientific manpower from abroad who can help to develop the quality of national researchers and ensure the establishment of a hi-tech research Laboratory. Also there should arrange efficient human resources and ample training programs for DoF personnel and technicians; create new position of more capable fishers regulatory officers to develop DoF as it is the key conscientious department for sustainable Hilsa fisheries management.

As sanctuaries are essential to protect Hilsa habitats, therefore, closing of particular areas to all types of harvesting and fishing at the time of spawning and cultivation periods can directly diminish fishing mortality rate. Although numerous managerial strategies had already been implied but there has been no accurate impact assessment of either the management wholly or the compensation schemes and close observations and monitoring for exact implication is yet to be pending. Government should establish managerial authorities who will implement strict actions to make successful previously formed strategies in reality. There should be an arrangement of public financial support permanently not as incentives; so that local fishers can take loans from the authorized government organizations and will not get deceit by the money lenders, micro-credit financial bodies of paying higher interest in return. As a result, fishers would become affordable to buy necessary fishing equipment, engine boats etc for their livelihood sustainability.

To reallocate the lawful regulations and compliances properly Government should arrange a survey team to collect data regarding the actual scenario of the fisheries management as well as fisher's life, channel of fish product distribution, marketing, exporting, importing and the behavior of the Governmental and law enforcement bodies. The Government should also impose legitimate serious action against administrative officials, securities and magistrates for unlawful misconduct like taking bribe from the fishers, money lenders during the expedition; and also focus on the procedures of incentives given by a chain of distributors to stop deceitfulness of the people. Besides, the Government must ensure adequate salary and other essential compensation for coast guards, police, securities and law enforcement agency workers to improve their working mobility towards their assigned duties.

Despite having restrictions by laws, fishers are still using monofilament nylon net (current jal), drift gill net, seine net, fixed gill net, set bag net (Behundi jal), clap net and surrounding net (Charghera jal). The Government should ensure the availability of optimum mesh size gill nets for common fishers in reasonable price; plus keep more stern monitoring procedure of not producing and using those banned nets at all. Law enforcement personnel's should take proper step to stop indecent fishing regulations by seizing the current net directly from the manufacturers rather than only from the fishers. The Government should make strong and strict rules and punishment against the manufacturers who violate the verdict of the legislations.

The strategies already developed by the marine fisheries department are protective but should not contradict to the precautionary principles. These strategies have already achieved the category of customary international law. For example, the Government has taken the decision to increase the license of trawlers for Exclusive Economic Zones (EEZ) in 2013 which was seriously judged as the breach of precautionary principles due to the rising chances of fishing overexploitation. Hence, Government should imply managerial strategies which should be reconcilable towards national precautionary principles.

There is a need to establish a security check post in front of the entrance hub of Meghna River with canals to stop illegal movements of small fisher's boats during ban season which will also assist Government to decrease patrolling cost.

The law enforcement administration should take necessary steps of mitigating pirating attacks to the fisher's boat and should entail strict restrictions and punishment rulings against the pirates. Furthermore, a universal regulatory 
measure should implement among Bangladesh, India and Myanmar to alleviate trans-boundary conflictions in fisheries management at the time of proliferation and juvenile nurture to boost up the Hilsa shad production; such as - bans and using mesh size. Hilsa biology and fishery management trans-boundary research could be excellent inventiveness in the direction of fishing welfare and communities; durability of Hilsa fisher's livelihood along with stakeholders as well.

To protect Hilsa fishers from several injuries, illness and death, the Bangladesh Government should give some facilities to fishers under Fishermen's Pension and Social Security Benefit Scheme such as: medical care, sickness subsidy, unemployment subsidy, old-age subsidy, family education subsidy, maternity subsidy, employment wound subsidy, invalidity subsidy etc. This system has already been practiced in Srilanka.

To control usage of power engine boats and illegal fishing gear, field-based mobile licensing system should launch. Moreover, international disciplinary regulations such as - bilateral and multilateral collaboration should promote in supervision, producing and operating spanning and migratory fish stocks.

Impose strict regulations should be provided for abiding rulings of climate change and environmental laws by scrutinizing the vessel movements of hauling toxic waste to prevent environmental pollution and ocean species destruction. Moreover, Bangladesh Government should establish an environmental department section under the supervision of DoF.

The Government must arrange educative and training programs to enhance awareness regarding Mobile Court operation and its derivatives among law enforcing bodies, coast guards, marine personnel's, DoF members, fishers and stakeholders. Moreover, respective departments should strict the rulings and punishments towards magistrates and other officials about the participation and presence for the duties; to mitigate the absence of legal personnel during operations.

\section{Conclusion}

This study assumes that after implementation of several positive initiatives towards Hilsa production and management, though the production of Hilsa and development of Hilsa fishery sectors are being boosted remarkably but however, there have some negative consequences among every sector of Hilsa fisheries along with improper implications of laws and jurisdictions. Therefore, it is still necessary to put effective institutional arrangements of imposing regulations and ensuring excellent authority in both national and international levels to overcome the existing challenges. Finally, this study demonstrates a number of propositions for implementing implicit policy regulations in particular areas which could be helpful to the development of Bangladesh Hilsa fisheries sector and economy in future.

\section{Compliance with ethical standards}

\section{Acknowledgments}

The authors express their sincere gratitude and special thanks to Prof. Ms. Chen Xin, Mr. Chen Ke Liang and Mr. Kajal Kanti Chowdhury for their valuable suggestions, cooperation and assistance to complete this study.

\section{Disclosure of conflict of interest}

All of the authors declare that they have all participated in the design, execution, and analysis of the a article, and that they have approved the final version. Additionally, there is no conflict of interest in connection with this article, and the material described is not under publication or consideration for publication elsewhere.

\section{References}

[1] Bangladesh Bureau of Statistics. (1991). Bangladesh at a Glance. Government of The People's Republic of Bangladesh.

[2] FAO. (2007). The State of World Fisheries and Aquaculture 2006. FAO Fisheries and Aquaculture Department, Food And Agriculture Organization of The United Nations, Rome, Italy. 
[3] FRSS. (2017). Yearbook of Fisheries Statistics of Bangladesh. Fisheries Resources Survey System (FRSS). In: Department of Fisheries, Bangladesh. Ministry of Fisheries and Livestock, Issue: April, 33.

[4] DoF. (2016). Fisheries Statistics in Bangladesh: Issues, Challenges and Plans. Asia and Pacific Commission on Agriculture Statistics, Department of Fisheries, Bangladesh. Issue: February, Agenda Item, 6(3), 15-19.

[5] DoF. (2018). Fisheries Statistics of Bangladesh 2017-2018. In: Fisheries Resources Survey System (FRSS), Department of Fisheries, Ministry of Fisheries, Bangladesh.

[6] Sunny AR, Hassan MN, Mahasin M and Nahiduzzaman M. (2017). Present status of hilsa shad (Tenualosa ilisha) in Bangladesh: a review. Journal of Entomology and Zoology Studies; E-ISSN:2320-7078, P-ISSN: 2349-6800, 5(6), 2099-2105.

[7] Bhaumik U. (2015). Migration of Hilsa Shad in the Indo-Pacific Region - A Review. International Journal of Current Research and Academic Review, 3(11), 139-155.

[8] Elahi SM. (2017). Hilsa Gets GI Recognition: Bangladesh to register Geographical Indication of Hilsa. The Financial Express, Bangladesh. In: The Finacial Express.

[9] Shamsuzzaman MM, Xiangmin X and Islam MM. (2016). Legal status of Bangladesh fisheries: Issues and Responses. Indian Journal of Geo-Marine Sciences, 45(11), 1474-1480.

[10] Mazid MA. (2018). An Overview of Aquaculture Development in Bangladesh: Role of Research. Journal of Bangladesh Agriculture, 8(1), 13.

[11] National Fisheries Policy. (1998). Ministry of Fisheries Livesock, Government of The People's Republic of Bangladesh, 1-18.

[12] DoF. (2006). National Fisheries Strategy, 2006. Department of Fisheries, Matshya Bhaban Ramna, Dhaka, Bangladesh, Issue: January, 1-22.

[13] MoFL. (1991). Ministry of Land Memorandum. Government of the People's Republic of Bangladesh, Pub. L. No. Bhum/7/5/91/424 (12), Section 2.

[14] Rahman MA, Jahan B, Lee S, Habibur M, Molla R and Shaikh MM. (2018). Fisheries management and governance in Bangladesh.

[15] MoFL. (1997). The Fish and Fish Products (Inspection and Quality Control) Ordinance. Ministry Of Fisheries And Livestocks, Government of The People's Republic of Bangladesh, Ord. NO. XX of 1983 (S.R.O. No. 276 Law/97).

[16] MoFL. (1983). The Marine Fisheries Ordinance. Ministry Of Fisheries And Livestock, Government of The People's Republic of Bangladesh, Ord. No.XXXV.

[17] United Nations Convention on the Law of the Sea (UNCLOS). (1982). Article no.135, Section, 1, 67.

[18] Pramanik MMH, Rahman MA, Ahmed T, Rahman F, Hasan MM, Khan MH and Mahmud Y. (2017). Gill Net Selectivity of Hilsa (Tenualosa ilisha) in Meghna River Estuary of Bangladesh. Journal of Aquaculture Research \& Development, 08(04), 8-11.

[19] The Protection and Conservation of Fish Act. (1950). Bangladesh.

[20] Islam MM, Mohammed EY and Ali L. (2016). Economic incentives for sustainable hilsa fishing in Bangladesh: An analysis of the legal and institutional framework. Journal of Marine Policy, 68, 8-22.

[21] Bangladesh Gazette. (2014). Ministry of Fisheries and Livestock (MoFL).

[22] Rahman MA, Pramanik MMH, Ahmed T, Hasan MM, Khan MH and Mahmud Y. (2017). Impact Assessment of Twenty-Two Days Fishing Ban in the Major Spawning Grounds of Tenualosa ilisha ( Hamilton , 1822 ) on its Spawning Success. Journal of Aquaculture Research and Development, 8(6).

[23] Bladon AJ, Mohammed EY, Hossain B, Kibria G and Milner-Gulland EJ. (2018). Evaluating the ecological and social targeting of a compensation scheme in Bangladesh. PLoS ONE, 13(6:e0197809), 1-19.

[24] Alam M. (2012). Hilsa fisheries management in Bangladesh: A paradigm in natural resources conservation. In: Anon (Ed.), Hilsa; Status of Fishery and Potential for Aquaculture, Proceedings of the Regional Workshop. The WorldFish, Bangladesh and South Asia Office, 224-238.

[25] DoF. (2005). The Inland Capture Fisheries Strategy. Department of Fisheries, Matshya Bhaban Rramna, Dhaka, Bangladesh, 15. 
[26] Mohammed EY, Ali L, Ali S, Hussein B, Wahab MA and Sage N. (2016). Hilsa's non-consumptive value in Bangladesh:Estimating the non-consumptive value of the hilsa fishery in Bangladesh using the contingent valuation method. In: WorldFish - International Institute for Environment and Development (IIED), London, ISBN 978-1-78431-425-5.

[27] Dewhurst-Richman N, Mohammed EY, Ali M, Hassan K, Wahab MA, Ahmed ZF, Islam MM, Bladon A, Haldar GC, Ahmed CS, Majumder MK, Hossain MM, Rahman A and Hussein B. (2016). Balancing Carrots And Sticks; Incentives for sustainable hilsa fishery management in Bangladesh. International Institute for Environment and Development, London, ISBN: 978-1-78431-334-0.

[28] Greiber T. (2009). Payments for Ecosystem Services, Legal and Institutional Frameworks; IUCN Environmental Policy and Law Paper. In: T. Greiber (Ed.); International Union for Conservation of Nature and Natural Resources (IUCN), Switzerland, Issue: 78.

[29] IIED (2014). Protecting ecosystems and livelihoods in Bangladesh. In: International Institute for Environment and Development, IIED, London.

[30] MoEF. (2009). Bangladesh Climate Change Strategy and Action Plan 2009 (BCCSAP). Ministry of Environment and Forests, Government of the People's Republic of Bangladesh, Dhaka, Bangladesh. Ministry of Environment and Forests, xviii+, 76.

[31] The Environmental Policy. (1992). In Chencery Law Chronicles. First Bangladesh Case Online Database. Government of The People's Republic of Bangladesh, 1-11.

[32] Wildlife (Conservation and Security) Act, 2012. (2012). ACT NO. XXX; Bangladesh, 1-17.

[33] Christie P, McCay BJ, Miller Ml, Lowe C, White AT, Stoffe R, Fluharty DL, McManus LT, Chuenpagdee R, Pomeroy C, Suman DO, Blount BG, Huppert D, Eisma RLV, Oracion E, Lowry K and Pollnac RB. (2003). Toward developing a complete understanding: A social science research agenda for marine protected areas. American Fisheries Society, 28(12), 22-26.

[34] Islam MM, Aktar R, Nahiduzzaman M, Barman BK and Wahab MA. (2018). Social considerations of large river sanctuaries: A case study from the hilsa shad fishery in Bangladesh. Journal of Multidisciplinary Digital Publishing Institute (MDPI) - Sustainability, Switzerland, 10(4), 1-17.

[35] The Convention on Biological Diversity. (2000). UNEP/CBD/COP/5/23. Annex III. Nyrobi, Kenya, 66-206.

[36] United Nations. (2019). Sustainable Development Goal14, Conserve and sustainably use the oceans, seas and marine resources for sustainable development. Economic and Social Council. In: United Nations portal.

[37] Blake B, Barr J and Peris C. (2003). Community Based Fisheries Management Project 2: Second Output To Purpose Review Report, Issue: October, The World Fish Centre, Dhaka, Bangladesh: Rural Livelihoods Evaluation Partnership, 2, 92.

[38] MoFL. (2006). Fisheries Sub-Sector Road Map for Implementation of PRSP Policy Recommendations, 2006 2015. Ministry of Fisheries and Livestock, Planning and Evaluation Wing/ Policy \& Planning Support Unit.

[39] Hosen GD and Ferdous SR. (2010). The Role of Mobile Courts in the Enforcement of Laws. The Northern University, Journal of Law. ISSN: 2218-2578,1.Avaiable: http:// www. banglajol.info/index.php/NUJL/article/view/18527.

[40] Siddiqui MS. (2011). Mobile court and independence of Judiciary. In: The Financial Express, Dhaka, Bangladesh ,18 (NO -301 REGD NO DA 1589).

[41] Pomery R, Thompson P and Courtney CA. (2017). Marine tenure and small-scale fisheries: Learning from the Indonesia experience and Recommendation for the Hilsa Fishery. Washington, DC: USAID Tenure and Global Climate Change Program. AID-OAA-T0-13-00016, 73.

[42] Waheb MA. (2019). USAID_Enhanced Coastal Fisheries in Bangladesh, ECOFISH-Bangladesh. Annual Report : Oct 2018 to Dec 2019. In: WorldFish. Donor Report.

[43] The World Bank. (2018). GDP Growth Annual (\%) - Bangladesh. World Bank national accounts data, and OECD National Accounts data files. License : CC BY-4.0.

[44] Haldar GC and Amin SMN. (2005). Population Dynamics of Male and Female Hilsa, Tenualosa ilisha of Bangladesh. Pakistan Journal of Biological Sciences, 8(2), 307-313. 
[45] Islam MM, Sallu SM, Hubacek K and Paavola J. (2014). Vulnerability of fishery-based livelihoods to the impacts of climate variability and change: insights from coastal Bangladesh. Journal of Regional Environmental Change. ISSN: 1436-3798, 14(1), 281-294.

[46] DoF. (2009). Fisheries Resources Survey System. In: Fisheries statistical Yearbook of Bangladesh 2007-2008. Department of Fisheries, Matshya Bhaban, Ramna, Dhaka, Bangladesh, 25(1).

[47] Amin SM, Rahman MA and Milton DA. (2008). Catch Per Unit Effort, Exploitation Level and Production of Hilsa Shad in Bangladesh Waters. Journal of Asian Fisheries Science. Asian Fisheries Society, Manila, Philippines, 21, 175-187.

[48] Sahoo AK, Wahab MA, Phillips M, Rahman A, Padiyar A, Puvanendran V, Bangera R, Belton B, De DK, Kumar D, Meena-Kumar, BB, Prakash A, Sharma U, Bhaumik U, Mohanty BP, Choudhury SR and Mohan CV. (2018). Breeding and culture status of Hilsa (Tenualosa ilisha, Ham. 1822) in South Asia: a review (2016). Reviwes in Aquaculture, 10(1), 96-110.

\section{How to cite this article}

Chowdhury K, Das NG, Rani S and Chowdhury S. (2020). Customary legislations and legal issues of Hilsa fisheries (Tenualosa ilisha) in Bangladesh. GSC Biological and Pharmaceutical Sciences, 11(3), 266-280. 